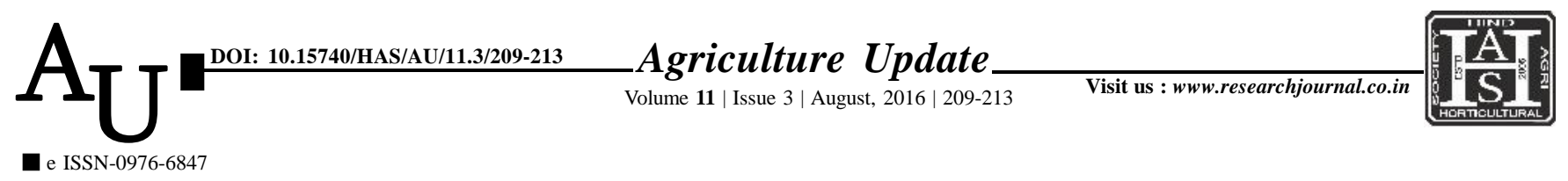

\title{
Research article: Constraints faced in production and marketing of sugarcane in Parbhani district of Maharashtra
}

\author{
RITESH A. CHAND, B.R. PAWAR AND M. KRISHNA
}

Article Chronicle:

Received :

03.05.2016;

Revised :

11.06.2016;

Accepted :

24.06.2016

\section{KeY WoRds:}

Constraints, Production,

Marketing
SUMMARY : The present paper entitled, constraints faced in production and marketing of sugarcane in Parbhani district of Maharashtra state was studied by selecting a sample of 60 sugarcane growers from 12 villages. Multistage sampling design was used in selection of district, tehsil, village and sample growers. Relevant data on various types of constraints faced and solutions anticipated were collected using a pre-tested structured schedule by personal interview method. The results of the study revealed that in Parbhani district at large, several constraints such as extreme drought condition, lack of finance and credit facilities, delay in transportation of cane, payments not done in time, non remunerative price of the produce, trouble by harvesting gang, poor road conditions, non-availability of ready use FYM, and inadequate irrigation facilities were amongst the major constraints faced by the growers. In order to overcome these constraints, 100 per cent of the respondents suggested that government should provide drip irrigation facility under strict monitoring scheme to all sugarcane growers in the region. Majority of the farmers strongly suggested that adequate provisions must be in place to ensure remunerative price is paid for the produce. In addition, a large number of growers submitted request if bank loan facility could increase at nominal interest rate at times when it's required the most.

How to cite this article : Chand, Ritesh A., Pawar, B.R. and Krishna, M. (2016). Constraints faced in production and marketing of sugarcane in Parbhani district of Maharashtra. Agric. Update, 11(3): 209-213, DOI : 10.15740/ HAS/AU/11.3/209-213.

\section{RITESH A. CHAND}

Department of Agricultural Economics, College of Agriculture, Vasanthrao Naik Marathwada Krishi Vidyapeeth, PARBHANI (M.S.) INDIA

See end of the article for authors' affiliations 